\title{
Energy Saving Potential of Radiant Cooling for Air- Conditioning in Buildings in Tropical Climate
}

\author{
[ Nupakon Kotcharak, Pipat Chaiwiwatworakul ]
}

\begin{abstract}
In the tropics, air-conditioning in buildings is highly energy-intensive. Radiant cooling is considered to be a potential means to conserve energy from air-conditioning. This paper presents results of an experimental and simulation study on application of a radiant cooling system in tropical Thailand. The system used radiant cooling panels to extract sensible heat from the experimental room. Heat pipe run around-coil heat recovery was used to handle the latent load from ventilation air and enhance its performance. By modeling the system using TRNSYS program, the simulations show that the radiant cooling system can save energy high upto 19 percent compared to the conventional air conditioning system.
\end{abstract}

Keywords-Radiant cooling, Thermal comfort, Tropical climate, Heat pipe, Ventilation

\section{Introduction}

Thailand is a country in tropical region. Air-conditioning by cooling has reached saturation in commercial buildings; however, it is now rapidly growing in urban and suburban residential houses. With a concern of the high energy-intensity of air-conditioning, an alternative approach of radiant cooling is examined for its application in the tropics. The radiant cooling has been applied successfully in Europe and North America where the ambient air is relatively dry [1-3]. It offers quiet comfort and energy efficiency superior to conventional air-conditioning system [4]. However, application of radiant cooling in hot and humid climate to achieve thermal comfort is a big challenge in the attempt of elimination of condensation problem of moist air.

This paper reports experimental and simulation results of a study on application of a radiant cooling system integrated with a dehumidified ventilation air system under Thailand's climate. A radiant cooling system was constructed at a laboratory room in Bang Khun Tien Campus, King Mongkut's university of Technology Thonburi (latitude $13.57^{\circ} \mathrm{N}$ and longitude $100.44^{\circ} \mathrm{E}$ ). Experiments were conducted to evaluate the system cooling load and the indoor comfort condition.

TRNSYS program was applied to model and simulate the operation of the radiant cooling system. The simulation results were compared with those from the experiments. It was also used to simulate the operations of the radiant cooling system with the whole year tropical climate data. The results display that the radiant cooling with dehumidified air ventilation can

Nupakon Kotcharak, Pipat Chaiwiwatworakul

King Monkut's University of Technology Thonburi Thailand achieve thermal comfort approach to conventional airconditioning system and there is energy saving potential compared to the other system.

\section{Experiment}

Fig. 1 shows the layout of the experimental system. For the experimental room, 3-inch polyurethane (PU) foam was installed as a layer of the exterior walls to reduce the external heat gain. The interior wall was also insulated with one-inch PU foam. To reduce heat gain from roof, three-inch fiberglass matt was laid over the ceiling.

The figure also shows a radiant cooling room. Two radiant panels: the one under the ceiling and the other on the west wall were installed in the room. The interior dimension of the radiant cooling room was $2.4 \mathrm{~m}$ width by $2.8 \mathrm{~m}$ length, and 2.4 $\mathrm{m}$ height from floor to ceiling. A $6 \mathrm{~mm}$ green glaze window with external shading was placed on the north wall. Chilled water supplied to the RC panels was produces by a heat-pump with cooling capacity of $10.8 \mathrm{~kW}_{\text {th }}$.

\section{A. Radiant cooling panels}

Fig. 2 shows the configuration of the radiant panels. The panels made from aluminum plate affixed with a series of parallel straight copper tubes whose ends were connected with two headers. One header distributes evenly chilled water over the panels. The other collects the chilled water from the panels.

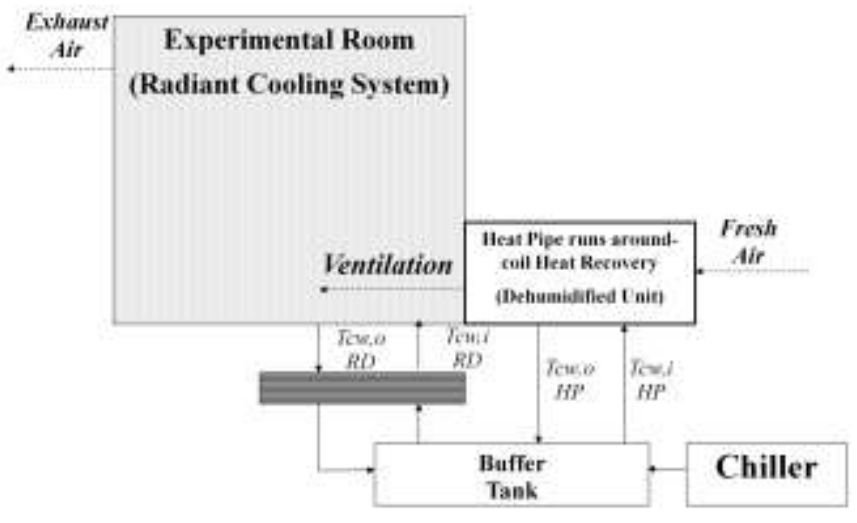

Figure 1. Layout view of the experimental system 


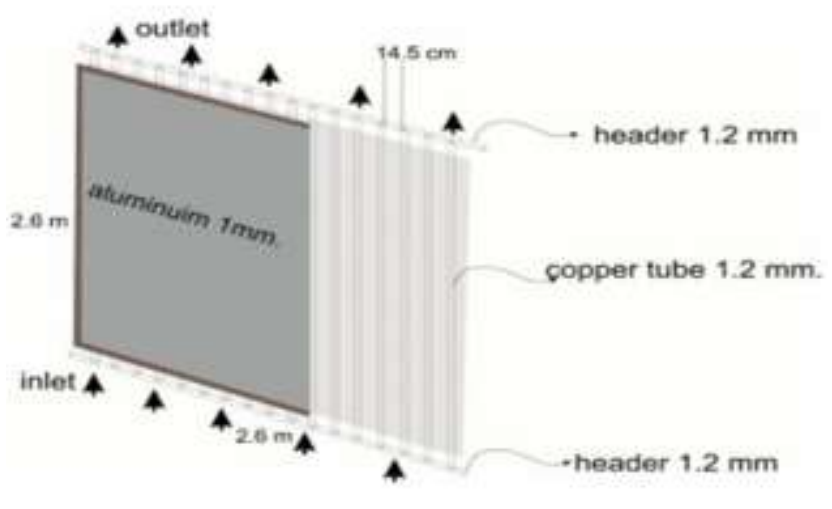

Figure 2. Configuration of radiant cooling panel

Insulation was placed to cover the tubes and beside of the panel in order to allow a due font surface heat transfer, heat loss reduction, and the acoustics improvement of the room. An entire surface of each panel was $5.8 \mathrm{~m} 2$. Chilled water at $18^{\circ} \mathrm{C}$ was supplied to the panels.

\section{B. Dehumidification unit}

Due to the constraint that the radiant cooling system can only handle sensible load, a dehumidification unit is necessarily integrated in order to handle the latent load. Chilled water at $10^{\circ} \mathrm{C}$ was supplied to the fan coil unit. In order to enhance the energy performance, the fan coil unit was equipped with a run around coil heat pipe to pre-cool the outdoor air intake and to reheat the cooled air exited from the fan coil.

\section{Internal load}

A person staying in the room is supposed as a wooden box with six $36 \mathrm{~W}$ fluorescent lamps with $6 \mathrm{~W}$ ballast were filled inside the box. Whole electrical energy supplied to lamps was assumed to become heat. So the total internal heat load in the radiant room was $252 \mathrm{~W}$. Surface temperature of the box was at $33^{\circ} \mathrm{C}$ from measurement when all lamps were turned on.

\section{Simulation Tool and Comfort Assessment}

A Transient Systems Simulation Program (TRNSYS) was applied to simulate operation of the radiant panels in the radiant cooling room. In the simulation, Module 56 of the program was used extensively. Incident solar radiation from weather data on the exterior wall surfaces of the rooms was calculated by a radiation processor module. Heat gain through walls and through window was calculated by Module 56 via energy balance by using provided input weather data and solar radiation. The weighted temperature of the mean radiant temperature of the surfaces in a zone and room air temperature were also computed. Thermal sensation scale for thermal comfort conditions [5] are shown in the Table I.

UC Berkeley thermal comfort program was adopted to calculate predicted mean vote (PMV) [6] for results from measurement and simulation including four given physical variables of dry-bulb temperature, relative humidity, mean radiant temperature and air speed. Also, two personal variables including clothing insulation value and metabolic rate are also required for PMV evaluation.

\section{Experimental Results}

The results of the experiments on 26 November 2014 is chosen for presentation. Temperature, absolute humidity, ambient air temperature and solar radiations in the experimental day are shown in Fig. 3. The global radiation varied over the days and peaked at $750 \mathrm{~W} / \mathrm{m} 2$. The diffuse radiation was measured lower than $400 \mathrm{~W} / \mathrm{m} 2$. Temperature of the ambient was in range of $26^{\circ} \mathrm{C}$ to $35^{\circ} \mathrm{C}$. As the experiment was conducted on rainy day, the outdoor air had moisture gain by absolute humidity was about 12 to $16 \mathrm{~g} / \mathrm{kg}_{\mathrm{da}}$. In addition, in the experiment chilled water was supplied to the panels at $18^{\circ} \mathrm{C}$ and temperature of supplied ventilation air varied from $19^{\circ} \mathrm{C}$ to $25^{\circ} \mathrm{C}$ depended on ambient air temperature, and air flow at 1 air change per hour.

Temperature of the room air of radiant cooling system room (Trm-rad-(M)) measured during the experiment is shown in Fig. 4. Althought a heat load from wooden box $(252 \mathrm{~W})$ was added in the radiant room. The room air temperature can be kept in range of $23^{\circ} \mathrm{C}$ to $25^{\circ} \mathrm{C}$. It can be observed that radiant cooling system is able to condition room air temperature. TRNSYS simulated the temperatures of the room air as a function of time, by input data of solar radiation and ambient air, and the configuration of the radiant cooling system and the experimental building. A good agreement between the measurements and the simulation is shown in this figure.

Temperatures of chilled water supply and return from the panels are displayed in Fig. 5(a) and (b). The heat extraction by the panels are shown and compared with results from TRNSYS simulation program. From the figure, the heat removal by wall panel was approximately $200 \mathrm{~W}$ on nighttime and $250 \mathrm{~W}$ on daytime. The total extracted heat by the radiant panels varied 400 to $500 \mathrm{~W}$ depended on time interval. It can be observed that the panels did not receive only heat from the hot-wooden box, but also carry from other loads from heat gain through the walls.

Fig. 6 shows the values of PMV from the corresponding values form measurements and output data from TRNSYS using UC Berkeley thermal comfort program. The PMV values from measurement were derived from the data of room air temperature, mean radiant temperature, relative humidity

TABLE I. ThERMAL SENSATION SCALE

\begin{tabular}{|c|c|}
\hline Thermal Scale & Value \\
\hline Hot & +3 \\
Warm & +2 \\
Slightly Warm & +1 \\
Neutral & 0 \\
Slightly Cool & -1 \\
Cool & -2 \\
Cold & -3 \\
\hline
\end{tabular}


Proc. of the Intl. Conf. on Advances in Applied science and Environmental Technology - ASET 2015. Copyright (C) Institute of Research Engineers and Doctors, USA .All rights reserved.

ISBN: 978-1-63248-040-8 doi: 10.15224/ 978-1-63248-040-8-33

of the room, and relative air velocity. And, The PMV values from simulation were derived from the corresponding parameters from TRNSYS. In addition, metabolic rate and clothing insulation were at 1.1 and 0.5 clo, respectively. From the figure, the PMV values are between -0.5 to 0 representing the neutral comfort condition.

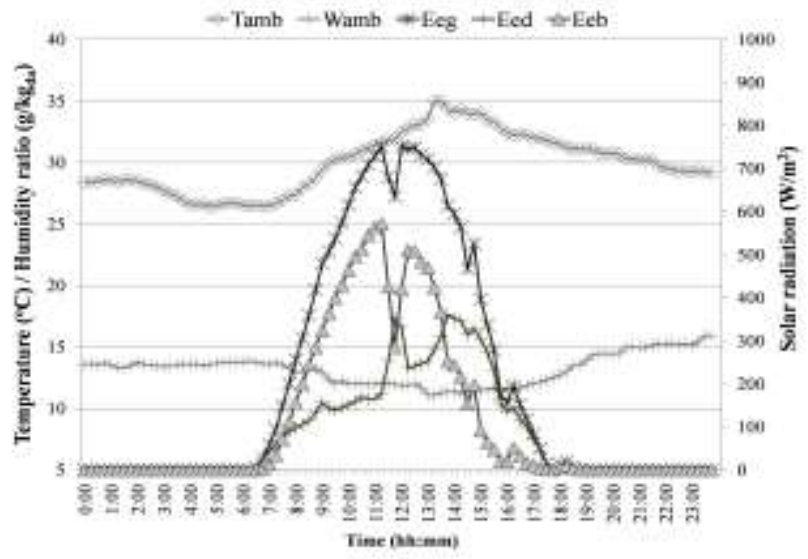

Figure 3. Weather data on 26 November 2014

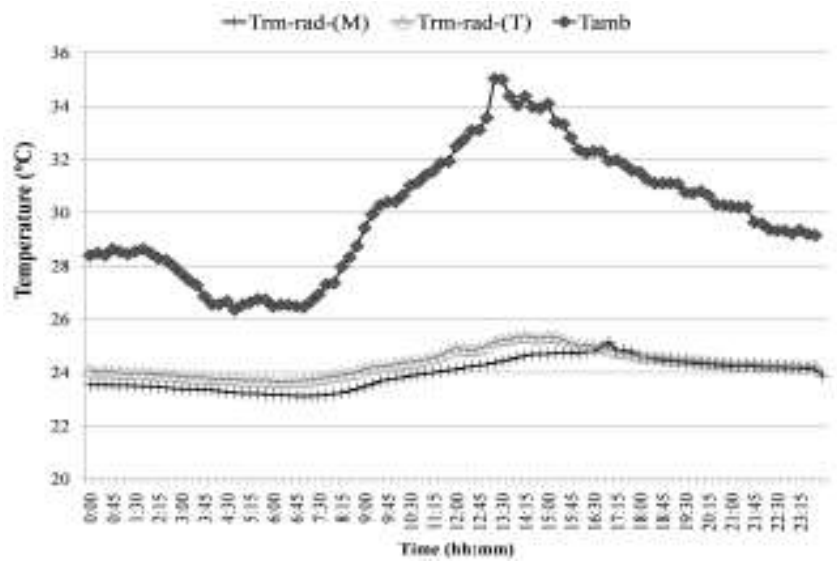

Figure 4. Temperature of ambient air and room air

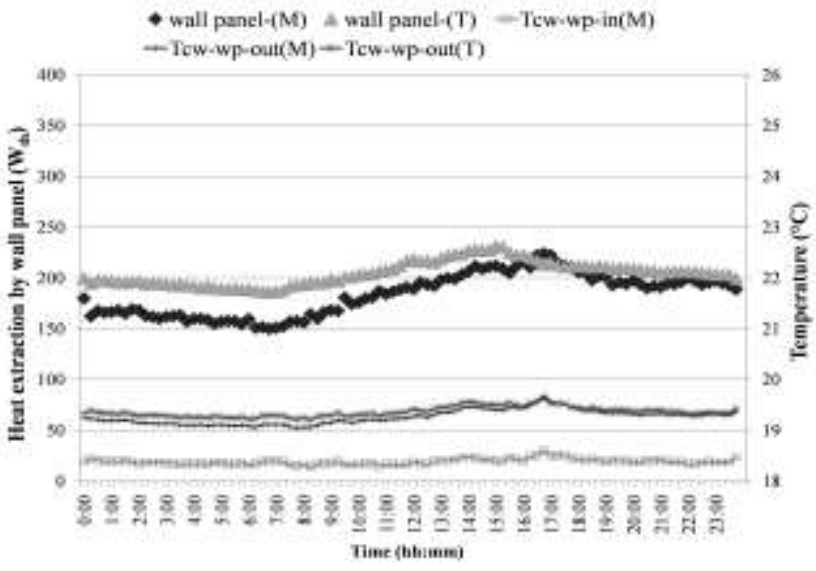

(a) Wall panel

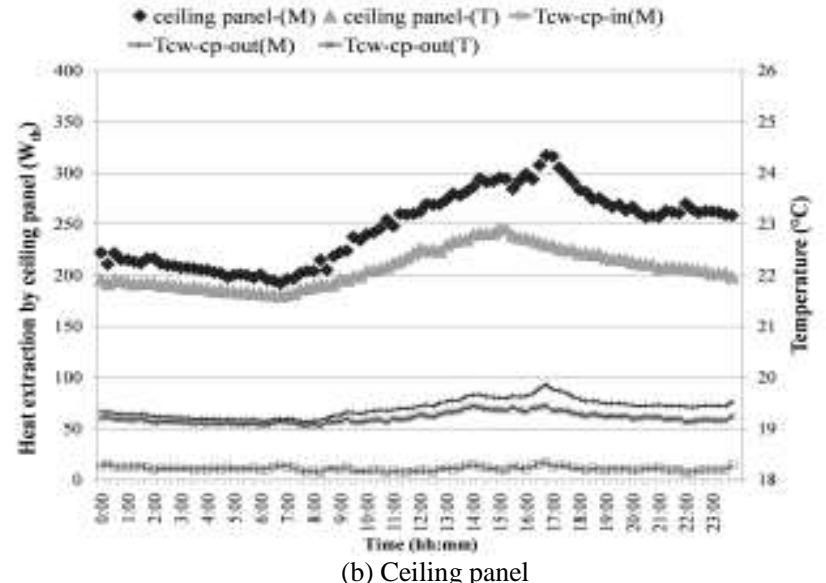

Figure 5. Heat extraction by radiant panels and temperature of chilled water

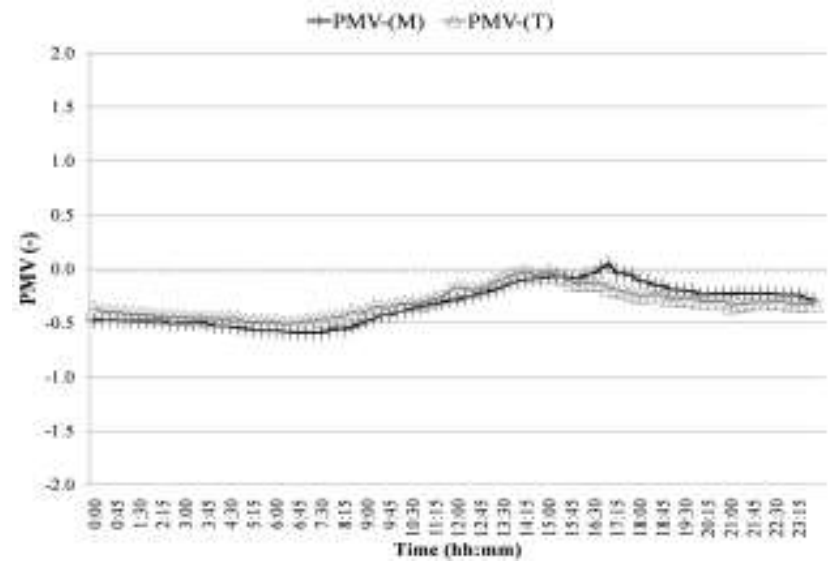

Figure 6. Value of predicted mean vote (PMV) of the room.

\section{Simulation Analysis}

The results in previous section show that TRNSYS could simulate the operation of the radiant cooling system with an acceptable level of accuracy. In this section, TRNSYS was used to perform the annual simulation to evaluate the performances of (i) a conventional air-conditioning system and (ii) the radiant system with dehumidified ventilation air unit.

For conventional air-conditioning system, the simulation was made for which the room air temperature was maintained at $24.5^{\circ} \mathrm{C}$. Air infiltration was set at $0.5 \mathrm{ACH}$. Table II shows the values of common parameters for TRNSYS simulation.

For radiant cooling system, the values of the parameters in Table II are still used and the room air velocity is assumed to be zero (in radiant room the velocity of indoor air is very low). Table III is also employed in simulation study of radiant cooling system. Temperature of chilled water supplied to the panels is adjusted in each period to achieve thermal comfort in the same level of conventional air-conditioning system.

The weather climates of Thailand can be divided into 4 periods including to cool and dry (1 November to 15 February), hot and dry (16 February to 31 May), hot and 
humid (1 June to 15 August), and late rain (16 August to 31 October). There are differences of ambient temperature and absolute humidity in each period used for weather data as input in TRNSYS.

From the simulation, the sensible and latent loads of the conventional air-conditioning system are presented in Table IV. It implies that the cooling load in a day varies in each period and latent load shares about $17 \%$ in cool and dry period, and $25 \%$ in other periods of the total load. Table V shows the cooling load in the radiant room that is lower than the first case. This would results from the lower indoor air velocity and the different heat transfer mechanism.

Table VI shows the thermal comfort condition [7] that can be achieved by radiant cooling system and conventional airconditioning system over a year. The comfort conditions are quite comparable for both systems.

Table VII demonstrates the electrical energy consumption for these two air condition system. Total electrical energy in each period and over a year can be calculated. The values were derived from total cooling load when define COP of chiller is 2.7 and power consumption of circulation fan of conventional air-conditioning system is $50 \mathrm{~W}$. Energy consumption of water pump and ventilation were neglected.

TABLE II. VALUES OF PARAMETERS IN YEARLY SIMULATION OF CONVENTIONAL AIR-CONDITIONING SYSTEM AND RADIANT COOLING SYSTEM

\begin{tabular}{|c|c|c|}
\hline & Parameter & Value \\
\hline \multicolumn{3}{|c|}{ Internal load } \\
\hline- & Human (Seated, very light writing, W) & 120 \\
\hline & Sensible load $(\mathrm{W})$ & 65 \\
\hline & Latent load (W) & 55 \\
\hline- & Light (1 lamp, W) & 40 \\
\hline- & Ventilation air $(\mathrm{kg} / \mathrm{h})$ & 30 \\
\hline- & Air change of infiltration $(1 / \mathrm{h})$ & 0.5 \\
\hline \multicolumn{3}{|c|}{ Daytime occupancy (Sedentary activity) } \\
\hline- & Operation time (hr) & $0.00-24.00$ \\
\hline- & Metabolic rate of occupant (met) & 1.1 \\
\hline - & Clothing insulation (clo) & 0.5 \\
\hline
\end{tabular}

TABLE III. ADDITIONAL VALUES OF PARAMETERS IN YEARLY SIMULATION OF RADIANT COOLING SYSTEM

\begin{tabular}{|c|c|}
\hline Parameter & Value \\
\hline Flow rate of supply chilled water $(\mathrm{kg} / \mathrm{h})$ & 150 \\
\hline Area of radiant panel $(\mathrm{m} 2)$ & \\
\hline - $\quad$ wall (west) & 5.76 \\
\hline - $\quad$ ceiling & 5.76 \\
\hline $\begin{array}{l}\text { Temperature of supply water in radiant cooling } \\
\text { system }\left({ }^{\circ} \mathrm{C}\right)\end{array}$ & \\
\hline - $\quad$ Cool and dry period (Daytime, Nighttime) & 18,20 \\
\hline - $\quad$ Hot and dry period & 17 \\
\hline - $\quad$ Hot and humid period & 17 \\
\hline - $\quad$ Late rain period & 17 \\
\hline
\end{tabular}

TABLE IV. COOLING LOAD HANDLED BY CONVENTIONAL AIRCONDITIONING VENTILATION SYSTEM IN A DAY

\begin{tabular}{|c|c|c|c|}
\hline Period & $\begin{array}{c}\text { Sensible } \\
\text { load }(\mathbf{W})\end{array}$ & $\begin{array}{c}\text { Latent } \\
\operatorname{load}(\mathbf{W})\end{array}$ & $\begin{array}{c}\text { Total } \\
\operatorname{load}(\mathbf{W})\end{array}$ \\
\hline Cool and Dry & 11,447 & 2,363 & 13,811 \\
Hot and Dry & 16,563 & 5,486 & 22,049 \\
Hot and Humid & 16,839 & 5,744 & 22,583 \\
Late Rain & 15,909 & 5,415 & 21,324 \\
\hline
\end{tabular}

TABLE V. COOLING LOAD HANDLED By RADIANT COOLING SySTEM IN A DAY

\begin{tabular}{|c|c|c|c|c|c|}
\hline \multirow{2}{*}{ Period } & \multicolumn{3}{|c|}{ Sensible load (W) } & $\begin{array}{c}\text { Latent } \\
\text { load (W) }\end{array}$ & $\begin{array}{c}\text { Total } \\
\text { load } \\
\text { (W) }\end{array}$ \\
\cline { 2 - 6 } & Panels & $\begin{array}{c}\text { Venti } \\
\text { lation }\end{array}$ & Total & $\begin{array}{c}\text { Venti } \\
\text { lation }\end{array}$ & \\
\hline & & & & & \\
Cool and Dry & 11,119 & 1,604 & 12,724 & 2,752 & 15,256 \\
Hot and Dry & 14,822 & 1,484 & 16,306 & 3,718 & 20,024 \\
Hot and Humid & 14,884 & 1,433 & 16,317 & 3,837 & 20,154 \\
Late Rain & 14,530 & 1,338 & 15,867 & 3,848 & 19,715 \\
\hline
\end{tabular}

TABLE VI. TRNSYS YEARLY SIMULATIONS FOR THERMAL COMFORT AND CONDENSATION EVALUATION

\begin{tabular}{|c|c|c|}
\hline \multirow{2}{*}{ Description } & \multicolumn{2}{|c|}{ Percentage of occurrence (\%) } \\
\cline { 2 - 3 } & $\begin{array}{c}\text { Conventional } \\
\text { A/C system }\end{array}$ & $\begin{array}{c}\text { Radiant cooling } \\
\text { system }\end{array}$ \\
\hline Too warm (PMV > 1.0) & 0.0 & 0.0 \\
Warm (0.5 < PMV < 1.0) & 4.8 & 2.8 \\
Comfortable (-0.5 < PMV < 0.5) & 95.2 & 95.2 \\
Cool (-1.0 < PMV <-0.5) & 0.0 & 2.0 \\
Too cool (PMV <-1.0) & 0.0 & 0.0 \\
Condensation (hr) & - & 0.0 \\
\hline
\end{tabular}

TABLE VII. ENERGY CONSUMPTION OF CONVENTIONAL AIRCONDITIONING SYSTEM AND RADIANT COOLING SYSTEM

\begin{tabular}{|c|c|c|c|}
\hline \multirow{2}{*}{ Period } & \multicolumn{2}{|c|}{ Energy consumption (kWh) } & \multirow{2}{*}{$\begin{array}{c}\text { Energy } \\
\text { saving (\%) }\end{array}$} \\
\cline { 2 - 3 } & $\begin{array}{c}\text { Conventional } \\
\text { A/C system }\end{array}$ & $\begin{array}{c}\text { Radiant cooling } \\
\text { system }\end{array}$ & 11.9 \\
Cool and Dry & 675.7 & 595.3 & 20.8 \\
Hot and Dry & 992.8 & 786.4 & 22.0 \\
Hot and Humid & 727.3 & 567.4 & 19.7 \\
Late Rain & 700.5 & 562.2 & 18.9 \\
Total in a Year & 3096.3 & 2511.3 & \\
\hline
\end{tabular}

From data above, it is observed that radiant cooling has potential to save energy high upto $20 \%$ hot-humid and rain season, and upto $12 \%$ in cool-dry season, and $19 \%$ over a year.

\section{v. Conclusion}

A radiant cooling system with a dedicated outdoor air system to prevent condensation problem was studied for application in building in tropical hot and humid climate. Such radiant cooling system is able achieve thermal comfort as same as conventional air-conditioning system. Also, this alternative air-conditioning system can save energy consumption. 


\section{References}

[1] Brunk, M.F., 1993. Cooling Ceiling - An Opportunity to Reduce Energy Costs by Way of Radiant Cooling, ASHRAE Transactions: Symposia, DE-93-2-1, pp. 479-487.

[2] Stetiu, C., 1999. Energy and peak power savings potential of radiant cooling systems in US commercial buildings, Energy and Buildings 30, 127-138.

[3] Mumma, S.A., 2001. Ceiling Panel Cooling Systems, ASHRAE Journal, November, 2832.

[4] Busweiler, U., 1993. Air Conditioning with a Combination of Radiant Cooling, Displacement Ventilation, and Desiccant Cooling ASHRAE Transactions 99(2), pp.503-510.

[5] ASHRAE, 2003, Standard 55 - Thermal Environmental Conditions for Human Occupancy. Atlanta, ASHRAE Inc.

[6] Fountain, M. E., and Huizenga, C., 1995. ASHRAE thermal comfort program version 1.0, University of California, Berkeley.

[7] EN ISO 7730. 1994. Moderate thermal environments determination of the PMV and PPD indices and specification of the conditions for thermal comfort, ISO Geneva. 